\title{
Lipopolysaccharide-induced acute phase response: New views on trace metal plasticity in hepatic inflammation
}

Ralf Weiskirchen*

Institute of Molecular Pathobiochemistry, Experimental Gene Therapy and Clinical Chemistry (IFMPEGKC), RWTH Aachen University Hospital, Germany

The term "acute phase" was originally introduced by Avery and colleagues to refer to serum obtained from patients who were acutely ill with infectious disease and which contained C-reactive protein (CRP) $[1,2]$. The acute phase reaction (APR) is a systemic reaction of the organism to local or systemic disturbances in its homeostasis caused by infection, tissue insult, trauma, or immunological disorders initiated and regulated by a large subset of cytokines. Most strikingly, the pattern of hepatic protein synthesis is drastically altered resulting in an increase of some plasma proteins. Generally, proteins whose concentration may increase by as much as $25 \%$ during the first week of injury or infection are classified as positive APR reactants [3]. At the same time, the production of several other proteins, i.e. negative APRs, is compensatory reduced. The measurement of positive and negative APR reactants as disease sensor is clinically useful because they are sensor of inflammatory disease [4,5]. The application of bacterial lipopolysaccharides (LPS), also known as endotoxin or lipoglycan, is a well-established experimental model for inducing APR in rodents [6]. Although the sensitivity toward LPS differs by several orders of magnitude between humans and mice, the quantitative and qualitative pattern of most APRs reactants and associated clinical symptoms are similar $[7,8]$.

Previously it was demonstrated that zinc deficiency enhances the APR, inflammatory response, and expression of APR reactants in vitro and in vivo through up-regulation of the JAK-STAT3 pathway [9]. Similarly, hypophosphophatemia clinically provoked stronger APR in critically ill patients by favouring the development of complications by impairing high-energy substrate availability for host defense and other cell functions [10]. Contrarily, severe iron deficiency blunted the response to LPS by blunting the activation of the NF- $\kappa \mathrm{B}$ pathway, induction of NF- $\kappa B$ responsive genes in macrophages and affecting hepcidin expression in hepatocytes [11]. In addition, modulator effects on ARP in cultured hepatocytes were described for selenium [12,13]. All these studies suggest that the status of diverse metals or metalloids impact the APR amplitude. However, a detailed analysis of trace metal kinetics after application of LPS was not reported yet.

In previous studies, my group optimized laser ablation inductively coupled mass spectrometry (LA-ICP-MS)-based protocols for trace metal imaging in liver sections from experimental Wilson's disease models and clinical samples of patients suffering from this inherited disorder [14-16]. These protocols have multi-element capability and allow the quantification of a large variety of metals and metalloids within the tissue with high spatial resolution. In brief, LA-ICP-MS is based on the ablation of tissue material by use of a finely focused laser beam. Subsequently, the ablated material is transported into the inductively coupled plasma source of a mass spectrometer using an inert carrier gas stream. There it is vaporized, atomized and ionized and the different elements are separated according to their mass/charge ratio [17].
By use of this methodology, we showed that copper agedependently accumulated in livers and brains of Atp $7 b$ deficient mice and simultaneously induced imbalances in hepatic iron and zinc content suggesting that the LA-ICP-MS technology is powerful and innovative in displaying complex changes in metal composition within a tissue [16].

The LA-ICP-MS technology was used here to analyse hepatic alterations in trace metals after LPS challenge. The endotoxin was injected into C57BL/6 wild type mice ( $\mathrm{n}=3$ per group) via the intraperitoneal route at $1 \mathrm{mg} / \mathrm{kg}$ body weight using standard operating procedures [6]. Control animals received an identical volume of vehicle (i.e. $0.9 \% \mathrm{NaCl}$ ). After one and six hours, the animals were sacrificed and the livers removed and snap frozen. $30 \mu \mathrm{m}$ thick tissue cryosections for LA-ICP-MS measurements of tissue were prepared and analyzed essentially under conditions reported before $[14,15]$. Images of element distributions were generated in Microsoft Excel and visualized with the help of the Excel Laser Ablation Imaging (ELAI) visualization tool as described before [18]. Standards were prepared from homogenized liver tissue that was spiked with varying concentrations of standard salt solutions.

While in this analysis, the hepatic concentration of manganese $(\mathrm{Mn})$, magnesium $(\mathrm{Mg})$, iron $(\mathrm{Fe})$, copper $(\mathrm{Cu})$, and zinc as images by LA-ICP-MS showed no gross alterations after LPS challenge, the content of phosphorus $(\mathrm{P})$ showed a significant increase already 2 hours after LPS injection that sustained for over 6 hours (Figure 1). The increase in $\mathrm{P}$ corroborated with increased hepatic potassium $(\mathrm{K})$ and a subsequent decrease in hepatic sodium $(\mathrm{Na})$.

In my view this preliminary pilot study demonstrates that LPS challenge in mice leads to an orchestrated program affecting hepatic concentrations of P, K and Na. Possibly, priming with LPS first provokes a redistribution of systemic $\mathrm{P}$ into the liver followed by a subsequent relocalisation of $\mathrm{K}$ acting as a positive counter-ion to restore the overall electric charge. Excess influx of $\mathrm{K}$ might be compensated in a second step by an efflux of $\mathrm{Na}$.

It is tempting to speculate that the redistribution of $\mathrm{P}$ from the periphery into the liver might be a necessity to initiate the different APR signalling cascades majorly activated by phosphorylation of

Correspondence to: Ralf Weiskirchen, Institute of Molecular Pathobiochemistry, Experimental Gene Therapy and Clinical Chemistry, RWTH-University Hospital, D-52074 Aachen, Germany, Tel. +49-241-8088683, Fax: +49-241803388683,E-mail: rweiskirchen@ukaachen.de

Received: December 03, 2017; Accepted: December 19, 2017; Published: December 23, 2017 


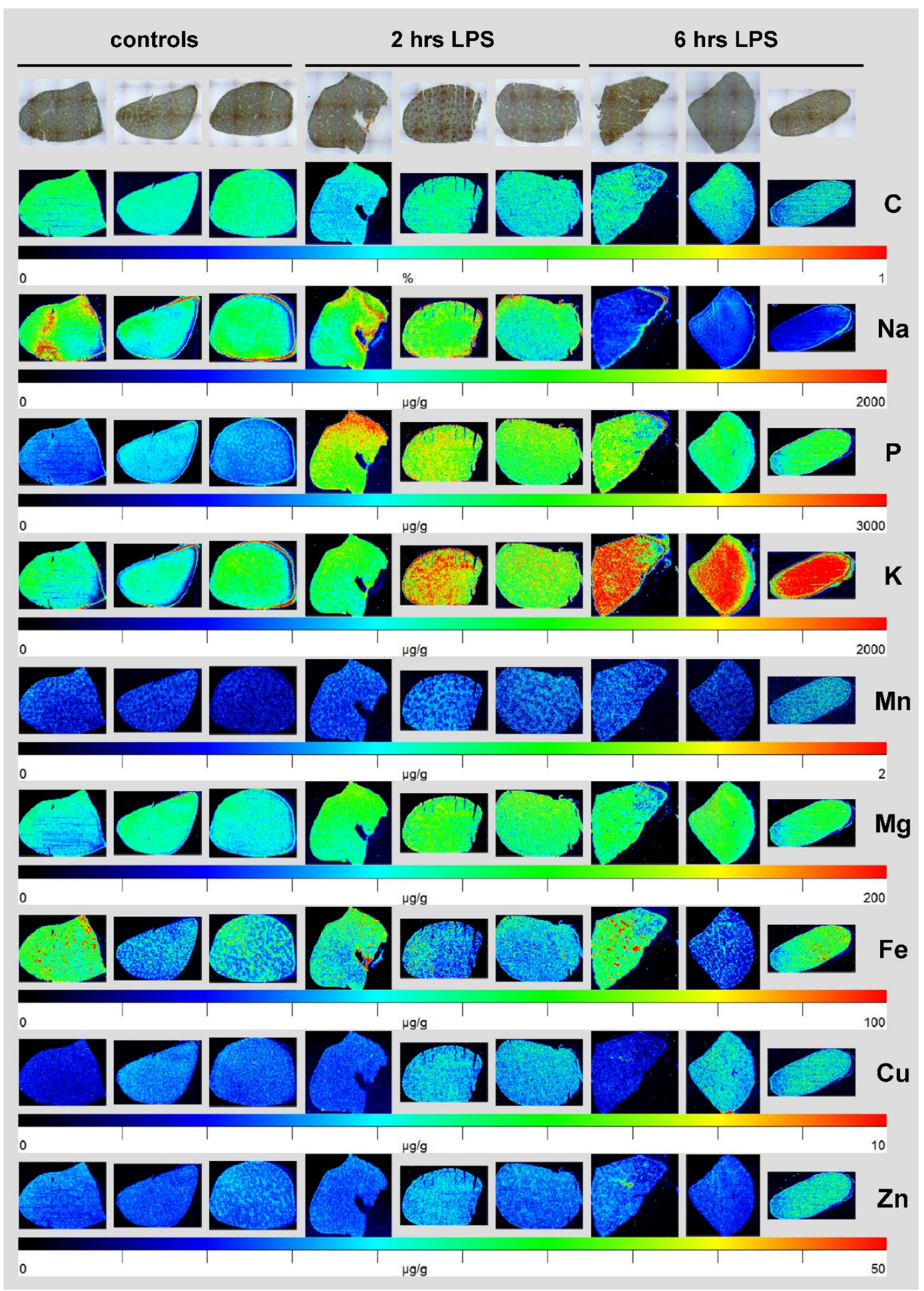

Figure 1. Element measurement by LA-ICP-MS in normal and inflamed mouse liver. Murine liver specimens were isolated two or six hours after LPS injection. Animals that received an equal volume of $0.9 \% \mathrm{NaCl}$ served as controls. The concentration and distribution of $\mathrm{Na}, \mathrm{P}, \mathrm{K}, \mathrm{Mn}, \mathrm{Mg}, \mathrm{Fe}, \mathrm{Cu}, \mathrm{Zn}$, and $\mathrm{C}$ was imaged by LA-ICP-MS. Light microscopic (LM) photographs of the respective liver specimens at a magnification of $4 \mathrm{x}$ are depicted for orientation. The determined element concentrations are visualized in a colour scale and are given in $\mu \mathrm{g} / \mathrm{g}$ liver tissue. C used for normalization is given in \%. More information about sample preparation, measurement, and data analysis are given elsewhere [16]. 
transcriptions factors rapidly resulting in production of acute phase proteins $[6,19]$. Alternatively, the observed pattern of element influx and efflux is secondarily provoked by diverse subsets of inflammatory cells infiltrating the inflamed tissue after endotoxemia [20].

To sum up, this study has shown that LPS injection in mice provokes significant element distributions within the liver. This set of experiments is far beyond to clarify the significance and the exact biological mechanisms leading to respective redistributions. However, the measurements depicted in Figure 1 indicate that the LA-ICP-MS technology allows documenting and quantifying respective changes.

In future studies, I and my research team will in more detail address the precise kinetics and biological consequences of metal alterations within hepatic tissue after challenge with diverse inflammatory triggers. Possibly such "new views on trace metal plasticity in hepatic inflammation" investigations will help to develop new therapeutic avenues for treatment of overshooting APRs.

\section{Comment on animal manipulation}

All mice used in this study received humane care and were housed according to the guidelines of Institutional Animal Care and Use Committees and in accordance with governmental requirements.

\section{Acknowledgement}

The author is grateful to Astrid Kueppers (ZEA-3, Forschungszentrum Jülich, Jülich, Germany) and Ricarda Uerlings (IFMPEGKC, RWTH Aachen University Hospital, Aachen, Germany) for excellent technical assistance in LA-ICP-MS measurements. In addition, the author acknowledges the help of Sorina G. Boaru previously working in my institute in performing the LPS injections.

\section{Grant support}

The author is supported by grants from the Deutsche Forschungsgemeinschaft (SFB/TRR 57 projects $\mathrm{P} 13$ and Q3) and from the IZKF Aachen (Project E7-6).

\section{References}

1. Abernethy TJ, Avery OT (1941) The occurrence during acute infections of a protein not normally present in the blood: I. distribution of the reactive protein in patients' sera and the effect of calcium on the flocculation reaction with c polysaccharide of pneumococcus. J Exp Med 73: 173-182. [Crossref]

2. Macleod CM, Avery OT (1941) The occurrence during acute infections of a protein not normally present in the blood: II. Isolation and properties of the reactive protein. $J \operatorname{Exp}$ Med 73: 183-190. [Crossref]

3. Kushner I (1982) The phenomenon of the acute phase response. Ann N Y Acad Sci 389: 39-48. [Crossref]
4. Peracaula R, Sarrats A, Rudd PM (2010) Liver proteins as sensor of human malignancies and inflammation. Proteomics Clin Appl 4: 426-431. [Crossref]

5. Jain S, Gautam V, Naseem S (2011) Acute-phase proteins: As diagnostic tool. J Pharm Bioallied Sci 3: 118-127. [Crossref]

6. Hamesch K, Borkham-Kamphorst E, Strnad P, Weiskirchen R (2015) Lipopolysaccharide-induced inflammatory liver injury in mice. Lab Anim 49: 37-46. [Crossref]

7. Warren HS, Fitting C, Hoff E, Adib-Conquy M, Beasley-Topliffe L, et al. (2010) Resilience to bacterial infection: difference between species could be due to proteins in serum. J Infect Dis 201: 223-232. [Crossref]

8. Reid RR, Prodeus AP, Khan W, Hsu T, Rosen FS, Carroll MC (1997) Endotoxin shock in antibody-deficient mice: unraveling the role of natural antibody and complement in the clearance of lipopolysaccharide. J Immunol 159: 970-975. [Crossref]

9. Liu MJ, Bao S, Napolitano JR, Burris DL, Yu L, et al. (2014) Zinc regulates the acute phase response and serum amyloid A production in response to sepsis through JAKSTAT3 signaling. PLoS One 9: e94934. [Crossref]

10. Giovannini I, Chiarla C, Nuzzo G (2002) Pathophysiologic and clinical correlates of hypophosphatemia and the relationship with sepsis and outcome in postoperative patients after hepatectomy. Shock 18: 111-115. [Crossref]

11. Darshan D, Frazer DM, Wilkins SJ, Anderson GJ (2010) Severe iron deficiency blunts the response of the iron regulatory gene Hamp and pro-inflammatory cytokines to lipopolysaccharide. Haematologica 95: 1660-1667. [Crossref]

12. Maehira F, Miyagi I, Eguchi Y (2003) Selenium regulates transcription factor NFkappaB activation during the acute phase reaction. Clin Chim Acta 334: 163-171. [Crossref]

13. Stoedter M, Renko K, Hög A, Schomburg L (2010) Selenium controls the sex-specific immune response and selenoprotein expression during the acute-phase response in mice. Biochem J 429: 43-51. [Crossref]

14. M-M P, Weiskirchen R, Gassler N, Bosserhoff AK, Becker JS (2013) Novel bioimaging techniques of metals by laser ablation inductively coupled plasma mass spectrometry for diagnosis of fibrotic and cirrhotic liver disorders. PLoS One 8: e58702. [Crossref]

15. M-M P, Merle U, Weiskirchen R, Becker JS (2013) Bioimaging of copper deposition in Wilson's disease mouse liver by laser ablation inductively coupled plasma mass spectrometry imaging (LA-ICP-MS). Int J Mass Spectrom 354-355: 281-287.

16. Boaru SG, Merle U, Uerlings R, Zimmermann A, Flechtenmacher C, Willheim C, Eder E, Ferenci P, Stremmel W, Weiskirchen R (2015) Laser ablation inductively coupled plasma mass spectrometry imaging of metals in experimental and clinical Wilson's disease. J Cell Mol Med 19: 806-814. [Crossref]

17. Susnea I, Weiskirchen R (2016) Trace metal imaging in diagnostic of hepatic meta disease. Mass Spectrom Rev 35: 666-686. [Crossref]

18. Uerlings R, Matusch A, Weiskirchen R (2016) Reconstruction of laser ablation inductively coupoled plasma mass spectrometry (LA-ICP-MS) spatial distribution images in Microsoft Excel 2007. Int J Mass Spectrom 395: 27-35.

19. Dayoub R, Buerger L, Ibrahim S, Melter M, Weiss TS (2017) Augmenter of liver regeneration (ALR) exhibits a dual signaling impact on hepatic acute-phase response. Exp Mol Pathol 102: 428-433. [Crossref]

20. McDonald B, Jenne CN, Zhuo L, Kimata K, Kubes P (2013) Kupffer cells and activation of endothelial TLR4 coordinate neutrophil adhesion within liver sinusoids during endotoxemia. Am J Physiol Gastrointest Liver Physiol 305: G797-G806. [Crossref]

Copyright: (C2017 Weiskirchen R. This is an open-access article distributed under the terms of the Creative Commons Attribution License, which permits unrestricted use, distribution, and reproduction in any medium, provided the original author and source are credited. 